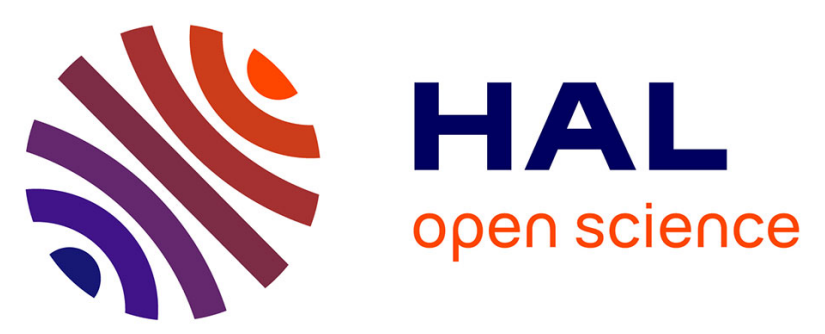

\title{
Familial risk factors in social anxiety disorder: calling for a family-oriented approach for targeted prevention and early intervention
}

\author{
Susanne Knappe, Katja Beesdo-Baum, Hans-Ulrich Wittchen
}

\section{To cite this version:}

Susanne Knappe, Katja Beesdo-Baum, Hans-Ulrich Wittchen. Familial risk factors in social anxiety disorder: calling for a family-oriented approach for targeted prevention and early intervention. European Child and Adolescent Psychiatry, 2010, 19 (12), pp.857-871. 10.1007/s00787-010-0138-0 . hal-00629463

\section{HAL Id: hal-00629463 \\ https://hal.science/hal-00629463}

Submitted on 6 Oct 2011

HAL is a multi-disciplinary open access archive for the deposit and dissemination of scientific research documents, whether they are published or not. The documents may come from teaching and research institutions in France or abroad, or from public or private research centers.
L'archive ouverte pluridisciplinaire HAL, est destinée au dépôt et à la diffusion de documents scientifiques de niveau recherche, publiés ou non, émanant des établissements d'enseignement et de recherche français ou étrangers, des laboratoires publics ou privés. 


\title{
Familial risk factors in social anxiety disorder: Calling for a family-oriented approach for targeted prevention and early intervention
}

\author{
Susanne Knappe, $\mathrm{PhD}^{1}$ \\ Katja Beesdo-Baum, $\mathrm{PhD}^{1}$ \\ Hans-Ulrich Wittchen, $\mathrm{PhD}^{1,2}$
}

1 Institute of Clinical Psychology and Psychotherapy, Technische Universitaet Dresden, Germany

2 Max Planck Institute of Psychiatry, Munich, Germany

For submission to: European Child \& Adolescent Psychiatry

Word count: 5,274

Abstract word count: 180

Corresponding author:

Susanne Knappe, PhD

Institute of Clinical Psychology and Psychotherapy, Technische Universitaet Dresden

Chemnitzer Str. 46

01187 Dresden, Germany

Phone: ++49-351-463-39727

Fax: ++49-351-463-36984

Email: knappe@psychologie.tu-dresden.de

Co-authors addresses:

Katja Beesdo-Baum, PhD

Technische Universitaet Dresden

Institute of Clinical Psychology and

Psychotherapy

Chemnitzer Str. 46

01187 Dresden, Germany

Phone: +49 35146336989

Fax: +49 35146336984

e-mail: beesdo@psychologie.tu-dresden.de
Hans-Ulrich Wittchen, $\mathrm{PhD}$

Technische Universitaet Dresden

Institute of Clinical Psychology and

Psychotherapy

Chemnitzer Str. 46

01187 Dresden, Germany

Phone: +49 35146338577

Fax: +49 35146336984

e-mail: wittchen@psychologie.tu-dresden.de 


\section{Abstract}

Within the last decade, social anxiety disorder (SAD) has been identified as a highly prevalent und burdensome disorder. Both the characterization of its symptomatology and effective treatment options are widely documented. Studies particularly indicate that SAD aggregates in families and has its onset in early adolescence. Given the family as an important context for children's cognitive, emotional and behavioural development, familial risk factors could be expected to significantly contribute to the reliable detection of populations at risk for SAD. Reviewing studies on familial risk factors for SAD argues for the importance of parental psychopathology and unfavourable family environment, but also denotes to several shortcomings such as cross-sectional designs, short follow-up periods, diverging methodologies and the focus on isolated factors. Using a prospective longitudinal study that covers the high risk period for SAD, including a broader spectrum of putative risk factors may help to overcome many of the methodological limitations. This review sets out to develop a more familyoriented approach for predicting the onset and maintenance of SAD that may be fruitful to derive targeted prevention and early intervention in SAD.

Keywords: social anxiety, family, parental psychopathology, intervention, prevention 


\section{Facets of social anxiety: Shyness, social fears, social phobia and social anxiety disorder}

The concept of social anxiety includes a variety of phenomena that may range from shyness to more or less isolated social fears, up to the clinically relevant diagnostic prototype of DSM-IV [4] defined social phobia or social anxiety disorder. To disentangle these terms is essential for an unbiased communication in clinical and research practice.

Shyness or timidy (sometimes also called diffidence or retentiveness) has often been associated with social anxiety [19, 74], and refers to a normal variation of behaviour in social situations. Shy individuals usually react inhibited in unfamiliar situations or in relation with unfamiliar people. Mostly, shyness is a transitory condition and people divest their shyness when getting used to the situation [20]. The majority of shy individuals do not experience extensive fear, dysfunctional cognitions, or panic-attack like bodily sensations, and thus do not suffer from severe functional impairment [39]. Shyness constitutes a non-pathological, common personality trait or temperamental concept $[46,108]$. Nevertheless, it may predispose a person to develop excessive social fears, especially when it is combined with substantial concerns about being shy and evidence that it has a detrimental effect of functioning $[39,88]$.

In contrast, social fears relate specifically to the consistent fear to act in a way that will be humiliating or embarrassing, or to be negatively evaluated by others. Social fears may manifest fairly isolated in only one or two situations, but may also be more pervasive in a wider range of situations. They include performance fears such as fear of public speaking or speaking in front of others, writing in public, reading aloud, entering a room, or taking tests. Other social fears relate to social interactions such as initiating and/or maintaining a conversation, talking to or dealing with others, using public restrooms, eating and/or drinking in public, or going to (social) activities or participating in social events. Unreasonably strong fears were found in $22.3 \%$ of male and in $32.2 \%$ of female adolescents aged 14 to 24 years [115]. Similarly, at least one fifth of adults reported unreasonable strong fears [31].

When social fears cause significant distress or interference with daily life, psychosocial functioning and role-fulfillments, the diagnosis of social phobia should be considered. According to the DSM-IV, social phobia is defined as the marked and persistent fear of social or performance situations in which the person is exposed to unfamiliar people or to possible scrutiny by others [4]. Since DSMIII-R [3], a specifier was introduced to distinguish between a circumscribed, more discrete (nongeneralised) and a generalised form of social phobia. About one third of social phobia cases are 
classified as the generalised subtype. However, uncertainty about the (existence of a) threshold for the more severe form and its possible association with avoidant personality disorder $[38,106]$ are discussed.

The term 'social anxiety disorder' was introduced in the DSM-IV-TR [5], because 'social phobia' could inadvertently suggest to represent a form of specific phobia, neglecting the severity associated especially with the more generalised subtype. Subsequently, we prefer the term social anxiety disorder (SAD), to better acknowledge the many facets and heterogeneity of social anxiety. We first report on the epidemiology and natural course of SAD, and then emphasise the role of familial risk factors for its targeted prevention and early intervention, calling for a more family-oriented approach towards SAD.

\section{Epidemiology of social anxiety disorder}

SAD is very common, with lifetime prevalences ranging from $0.5 \%$ [110] in a Korean sample to $13.3 \%$ [54] in the US. Rates for 12-month prevalences or more narrow time frames similarly vary considerably from $0.4 \%$ [79] to $7.9 \%$ [54], probably due to different sampling, study designs, assessment strategies and applied diagnostic criteria. Overall, the average lifetime prevalence is about $6.7 \%$ and about 2.0 to $3.0 \%$ [32] for the last 12 months. SAD is almost twice as often present in females than in males $[24,62,115]$ and is associated with a decline in school or work performances, (school) refusal, and disinterest in age-appropriate activities [82]. SAD often hampers affected individuals from pursuing their academic achievements, leading to lower educational attainment [47, 85], impaired work-performance, underemployment and lower household-income and subsequently high levels of financial dependence and lower socio-economic status [23, 61].

SAD places a substantial strain upon the health care system [2], with only few costs related to SAD-specific treatment such as psychiatric and non-psychiatric care, hospitalization, and prescription drugs. Among the anxiety or mood disorders, SAD has the lowest treatment rates [44, 85, 95], probably because the disorder is hardly detected by primary care physicians, affected individuals are afraid to disclose an illness condition, or because of financial strains and uncertainty over where to seek help [81]. Less than $20 \%$ of affected individuals seek professional help [32, 84]. Most (indirect) costs are due to occupational disability like reduced productivity, absenteeism from work and suicide $[47,62]$. 


\section{Natural Course: Age of onset, duration, remission and patterns of course}

Most adults with SAD fail to recall the first onset of SAD symptoms or to remember a time when SAD was not a problem. Age of onset from retrospective reports of clinical studies was located in late adolescence and adulthood $[48,113]$. Therein, age of onset may reflect the point in life at which symptoms have led to severe impairment requiring treatment, after the disorder has been present for a considerable proportion of years. In contrast, studies based on representative community samples that included adolescents, age of onset was corrected towards an earlier onset between ages 10 to 16.6 years [113]. The high risk period for SAD was found to increase steeply after the age of 9 and then gradually decreased [10]. Onset of the disorder after 20 years of age is rare, and no further peaks for incidence are expected.

Mean duration for SAD symptoms ranges from 19 to 21 years in clinical studies, and from 19 to 25 years in community studies $[31,113]$. SAD does therefore not appear to be a transitory condition in adolescence and young adulthood. In the absence of effective treatment, SAD follows a chronic, unremitting course, that may also increase the likelihood of comorbid or subsequent other mental disorders.

SAD symptoms may not be consistently present on the DSM-IV diagnostic threshold level, as affected individuals also experience periods of lower symptom load or even symptom-free-periods. For example, among those with a lifetime SAD diagnosis, often less than one third also report SAD within the last 12 months [9], and individuals rarely meet the threshold for SAD consistently at subsequent assessment waves [72]. Accordingly, SAD may fluctuate in severity $[9,59]$, but persists on a symptom level with frequent oscillations around the diagnostic threshold [114]. About half of SAD cases have syndromal shifts [48], which is similarly observed in other anxiety disorders. Adolescent SAD is associated with SAD in adulthood [87], other anxiety [59], depressive [10, 100], and substance use disorders [55, 117], suggesting both homotypic and heterotypic continuity of SAD.

Although effective treatment is available, the chance for complete and long-lasting remission from SAD is the lowest among all anxiety disorders, especially in the generalised subtype and in the presence of comorbidities like avoidant personality disorder [89]. Remission is most likely in the first years after onset when complications of the disorder or comorbidities have not yet developed [118]. Remission rates in adults are often derived from the consecutive observational studies of the HarvardBrown Anxiety Research Program (HARP). Depending on the lenght of follow-up periods, full remission rates vary between $35 \%$ and $75 \%$ [48]. Because remission criteria in the HARP studies refer 
to the absence of symptoms for only eight consecutive weeks, remission rates are however likely overestimated. The relapse rate, once recovery was achieved, was $34 \%$, and increased to $75 \%$, when depression is comorbid [16]. As time to second relapse was shorter than the time to first relapse, duration of the symptom-free interval appears to decrease over time. In children and adolescents, spontaneous remission rates are usually higher than in adults (up to $50 \%$ after 15 month [30]), but reduce when also subthreshold expressions of $S A D$ and subsequent incidence of other anxiety disorders are considered [10,59].

Probably due to the waxing and waning of symptoms, predictors for an unfavourable course of SAD remain unspecified. In the HARP-studies, female gender, early age of onset, longer duration of illness, lifetime history of various anxiety disorders, current comorbidity of anxiety or depressive disorders, low global functioning or measures of role functioning were not associated with lack of remission or stability of symptoms [90]. In the same study, however, women were more likely to follow a chronic course than men, especially when the global functioning at study entry was low and they had a history of suicide attempts [118]. In adolescents, presence of SAD symptoms from baseline to 15 month follow-up was predicted by higher age, comorbid anxiety, somatoform and substance use disorders, but not by female gender, comorbid depressive disorders and attachment style [30].

\section{\#\#\#Box 1 starts here\#\#\#}

SAD is the most prevalent anxiety disorder, with first onset in late childhood and early adolescence. In the absence of effective treament, symptoms persist, often waxing and waning around the diagnostic threshold and increasing the likelihood for a range of comorbid disorders, and psychosocial maladjustment in the long run. Given the demonstrated size and burden of SAD, reliable factors are warranted to identify individuals at risk for $S A D$ as early as possible, and to allocate them to prevention and once SAD has manifested, to targeted intervention.

\#\#\#Box 1 ends here\#\#\#

\section{(Familial) risk factors for social anxiety disorder}

Traumatic events, peer relationships, social skills deficits, social cognition/information processing have been discussed as putative risk factors for SAD [89]. Since the high risk phase for 
SAD onset is located in late childhood/ early adolescence, familial risk factors are likely to be particularly important for targeted prevention and intervention in SAD 1 .

Parental SAD and other mental disorders. Family and high risk studies in clinical and community samples demonstrated that SAD aggregates in families (Table 1). Socially anxious children are more likely to have parents with SAD.

- Please insert Table 1 about here -

In family (genetic) studies that often excluded probands with comorbid anxiety disorders, relatives of socially phobics were at higher risk for social phobia exclusively [33, 34, 91]. Findings are defeasible by small or clinical samples, retrospective or indirect assessment of psychopathology in only one family member instead of direct interviews, and differences between parent and child reports. Studies also sometimes fail to observe double-blind diagnostic evaluation.

This susceptibility does not appear to be limited to parental SAD, as other parental anxiety, depressive or alcohol use disorders have also been shown to be associated with offspring SAD above $[15,33,58,69]$, and below the diagnostic threshold [57]. The SAD-specific parent-to-offspring transmission though appears to be limited to DSM-IV threshold SAD [57]. Thus, the familial transmission of SAD is probably characterised by low to modest specificity, and is likely to be determinated by cross-disorder risk factors, as well as family-based developmental conditions.

The familial aggregation is often reported to be stronger in the generalised subtype, indicating that this is the more familial form of the disorder. This conclusion is based on studies $[33,68,100$, 101], which have also been subject to criticism. Findings were limited by the number and specific types of situations assessed, and there was no evidence that patients with the generalised subtype were more likely to transmit the generalised form [68]. Findings were not compared to relatives of nongeneralised social phobics [100], and have not yet been replicated in independent samples. In one of our own studies [58], we used the number of social fears as a proxy for the generalised SAD subtype. Therein, associations between the number of offsprings' social fears were most pronounced in the

\footnotetext{
${ }^{1}$ Selection of the studies was based on literature research in PubMed, Web of Science and Psyclnfo, using the keywords "social anxiety", "anxiety", "social phobia", "family", "parents", including studies from 1989 to present. With regard to studies on family environment, we focus on studies in offspring $\leq 18$ years of age.
} 
presence of parental SAD, other anxiety disorders, and depression, but not parental alcohol use disorders, suggesting a possible familial liability for internalising disorders.

Twin and adoption studies may help to further dissect the familial aggregation into that due to genetic and environmental factors. Up to date, no adoption study on SAD is available. Most of the twin studies have been conducted by Kendler and co-workers [49-51] using data of the Virginia Twin Registry (Table 2). Heritability of SAD ranges from 0.20 to 0.50 , indicating that the phenotypic variation is moderately attributable to additive genetic factors. It is also suggested that men and women differ in the extent to which genetic and environmental factors contribute to SAD: Twin resemblance was best explained by (non-shared) factors of family-environment in females, and by (shared) genetic factors in males. Findings have been variously questionned. Particularly, those of the Kendler-studies were not always replicable (cf. [40]; for findings in other twin samples also cf. [27, 73]). For example, no effects of non-shared environment were found in the Missouri Adolescent Female Twin Study [78]. More generally, heritability estimates may be artificially inflated, as monozygotic twins may experience more similar environments than dizygotic twins. Also, dizygotic twins may differ from monozygotic twins in gestational periods in a way that could also lead to overestimation of heritability in monozygotic twins [29]. So far, the overall heritability of SAD appears to be modest, and familial resemblance in both males and females with SAD is at least in part due to genetic factors [49].

- Please insert Table 2 about here -

Some studies have linked the familial aggregation of SAD with behavioural inhibition (BI; [11, 93]. $\mathrm{BI}$ is defined as a temperamentally based disposition, characterised by fear, avoidance or restraint and withdrawal in both social and non-social unfamilial events [46]. The association between $\mathrm{BI}$ and anxiety disorders was found to be more pronounced in children of parents with anxiety disorders [41], and vice versa, increased rates of anxiety disorders were seen in parents of inhibited children. Hence, the association between BI and anxiety disorders is familial, perhaps genetic [29], and $\mathrm{BI}$ may serve as a genetic liability to develop SAD and other anxiety disorders. Accordingly, twin studies demonstrated a genetic component to $\mathrm{BI}$, with heritability ranging between $0.4-0.7$ at 14 to 24 month [26, 92]. Beyond $\mathrm{BI}$, also the role of (heritable) anxiety related traits such as higher levels of 
neuroticism, lower levels of extraversion or high introversion [12] and harm avoidance [65] have been found to be positively associated with lifetime SAD.

Both the familial aggregation and the associations with temperamental (risk) factors stimulated the search for genetic polymorphisms that contribute to the endophenotype of SAD [65]. Up to date, few studies examined potential candidate genes. Therein, the role of specific genes encoding components of serotonergic (5-HT) and dopaminergic pathways in patients with SAD appears crucial for SAD [28, 35]. Their true value however remains unclear until conditions for the expression of these candidate genes, and their association with other (anxiety) disorders have been clarified and validated.

Unfavourable family environment. Genetic factors appear to play only a modest (but nevertheless significant) role in the familial transmission of SAD. Some researchers suggest that family environment might be even more predictive for offsprings' mental health than parental diagnostic status [111]. Diverse family processes are suggested to provoke an enhancement of anxious and avoidant responses in children [8], such as insecure attachment [13,103], higher levels of expressed emotion [104], excessive family cohesion [86, 107], and disturbed family functioning $[7,105]$.

Table 3 summarizes (however not exhaustively) studies on the associations between unfavourable parental rearing styles and offspring anxiety. Because few studies particularly focus on offsprings' SAD, studies on anxiety in general or on a broader symptomatic level were also taken into account. Parental rearing may be shared alike by all children in the family, but it is a unique factor, as the rearing style of parents is tailored to the specific child [13, 43].

\section{- Please insert Table 3 about here -}

Retrospective studies in adolescents and young adults found lower levels of parental emotional warmth, higher levels of parental overprotection and rejection to be associated with offspring SAD [15, 58,64]. These findings have been questioned, as affected offsprings' reports may be subject to information processing [21] or attributional bias due to their psychopathology $[1,112]$. Though this may apply to some findings, observational studies provide further evidence for the role of unfavourable family environment for offspring SAD [96]: For example, mothers of anxious children initiated more control, more involvement and negativity [42] than mothers of unaffected offspring. 
The complex steps of the transformation from parental rearing into particular behaviour or psychopathological disturbances are fairly unexplored. Findings are often interpreted in terms of social learning mechanisms [83], such as parental modelling of anxious or avoidance behaviour $[25,75,76]$, or parental attitudes and actions $[14,111]$ by which parents actively manage the child's behaviour [e.g., 77].

At least two types of family processes are probably involved in the familial transmission of (social) anxiety [13]: On the one hand, harbouring threat and/or providing insufficient protection from it, and promoting threat sensitivity and/or impeding the development of coping skills on the other hand may be contribute to offspring anxiety. Normatively, parents facilitate their children's social interaction by arranging play dates, supporting participation in sport clubs or activities with peers. Parental overprotection or lack of emotional warmth may prevent offspring from acquiring social skills [89], increase the offsprings' dependence upon their parents [116], prevent exposure and habituation to social interactions, thereby reinforcing the child's anxiety and hampering the development of control, mastery and autonomy [89, 96 116]. Parents of anxious children may be more likely to become overinvolved with their child when attempting to reduce and prevent the child's distress. This rearing behaviour would in turn reinforce the child's anxiety by promoting negative beliefs about the world as a dangerous and uncontrollable place. Children who experience critical comments, rejection or feelings of shame by their parents may become preoccupied with evaluative components, leading to fear of negative evaluations, public self-consciousness and avoidance of social scrutiny [17]. Overprotective parenting limits the offsprings' opportunities to access information that might disprove or correct inaccurate fear information, and preclude from unprejudiced and positive social interactions. Otherwise, positive learning experiences from social interactions may be devaluated by parental critique.

Regardless of their plausibility, findings are challenged in two respects: First, McLeod, Wood, and Weisz [70] summarized that higher levels of parental 'control' or 'rejection accounted for only $6 \%$ and $4 \%$, respectively, of the variance and therefore only moderately predict offspring anxiety. The association between parental rearing and offspring anxiety was largely affected by a range of methodological artefacts (conceptualizations of anxiety and parenting, assessment strategies, sample characteristics). Most importantly, rearing styles such as 'control' or 'rejection' are often conceptualized as bipolar dimensions with positive parenting at the one end and negative parenting at the other, probably ignoring underlying sub-dimensions of rearing behaviour. In fact, the amount of 
explained variance in offspring anxiety increased to $42 \%$ when autonomy-granting as one particular facet of parenting was considered. Second, findings do not sufficiently explain the underlying mechanisms of the relationship between unfavourable family environment and offspring SAD, and their specificity (i.e., relative to other anxiety disorders). Recent (experimental) studies suggest that it may not be parental rearing per se that leads to offspring SAD. Rather, some of the characteristic features of offspring SAD (e.g., interpretational bias, sensitivity to stressful or threatening events or avoidance behaviour) may be specifically transmitted through the cognitive style of parents [63]: Parents' verbal threat information may induce anxious cognitions, attentional bias to threat, and avoidance behaviour. In addition, non-verbal transmission processes such as observation of others reactions to social stimuli such as parental [75] or maternal facial expressions [77], and maternal behaviour in social situations [25] may occur. There is however yet little evidence available on whether parent and offsprings' bias are correlated, and if a causal mechanism behind this association can be established. Interestingly, parents with higher trait anxiety may be more likely to disambiguate situations in a threatening way for their offspring, just like if parents were 'training' their offspring towards a general tendency to interpret ambiguity in a threatening way [63]. Also reciprocal influences remain understudied.

\#\#\#Box 2 starts here\#\#\#

Parental psychopathology (e.g., genetics) appears to play only a modest, albeit non-specific role for the development of SAD. Family environment constitutes an important, and probably more specific familial risk factor for offspring SAD. The underlying mechanisms from parental psychopathology and/or parental rearing to offspring SAD are still under investigation, focussing on parents' harbouring of threat (or providing insufficient protection from it), and impeding the development of their offsprings' skills through parents' cognitive style. Understanding of the parent-to-offspring transmission is however hampared because studies often focus on either parental psychopathology or family environment.

\#\#\#Box 2 ends here\#\#\#

\section{Interplay of parental psychopathology and family environment}

Heritability estimates suggest that "genetic factors play a significant but by no means overwhelming role in the aetiology of phobia" [52] (p. 279). Parental psychopathology may 
unspecifically prone an individual at risk to develop SAD (or any other mental disorder), but its interaction with individual specific factors (i.e., family environment) appears pivotal for the development and course of offspring SAD (in contrast to other offspring disorders): Affected parents have difficulties modelling appropriate coping strategies, by reacting towards their children's fears negatively because they represent an aspect of themselves which they would rather deny, or becoming overly concerned about their children's anxiety, resulting in overprotection and reduced opportunities for desensitization. In addition, affected parents may be limited in their ability to help their children to cope with SAD or to join social groups [82].

Empirical evidence for an interaction of parental psychopathology and familial environment on SAD is yet scarce. In one of our own studies [58], we found the risk for offspring SAD to be particularly elevated in offspring whose parents had an anxiety, depressive or alcohol use disorder and who reported greater overprotection, lack of emotional warmth, dysfunctional problem solving, role behaviour or behaviour control, as compared to offspring of unaffected parents reporting a more favourable family environment. Notably, interactions with unfavourable parental rearing styles (overprotection, rejection, lack of emotional warmth) were most pronounced in offspring of parents with SAD. Similarly, parent-to-offspring transmission of cognitive bias was found to be more likely if parents have an anxiety disorder, and if parents' biases extend beyond their own environment into their offsprings' environment [63], expected their offspring to make threatening interpretations of ambiguous situations [63], demonstrated greater negative and less positive expectations on their children's future performance, and responded to potentially threat provoking situations with catastrophizing [107] and avoidant solutions [22] than unaffected parents. The mediator/moderator role of parental psychopathology and unfavourable rearing styles has though yet to be examined. Results of Turner et al. [107] suggest a moderator role of parental psychopathology: Albeit they found that anxious parents did not restrict their children from playing or outgoing, anxious parents overtly expressed their concern and reported lower cohesion, expressiveness and higher conflict and achievement orientation than non-anxious parents. In addition, McClure et al. [69] did not find a mediating role of parenting between maternal and child anxiety disorders, suggesting that affected children are more likely to perceive their parents negatively if their parents also have an anxiety disorder (in contrast: [58]).

Also other factors such as offspring temperament likely exert their influence on the transactive parent-offspring-relationship, e.g., shy temperament may elicit overprotective parenting [67, 94]. 
Parents may react overinvolved to reduce the child's distress, reinforcing the anxious temperament and keeping the child from learning or making the child rather focus on avoidance [89]. Notably, parenting practices that promote child social anxiety are particularly likely to occur in anxious parents in the context of child inhibited, anxious or negative behaviour [77, 94]. Anxious parents may overestimate their children's vulnerability, anticipate catastrophic outcomes in potentially threatening situations, and respond by promoting avoidant solutions to challenges $[25,116]$.

\section{\#\#\#Box 3 starts here\#\#\#}

In terms of a vulnerability-stress model, parental psychopathology may represent a more general (heritable) basis, that prones their offspring to develop SAD (and probably other disorders as well). In contrast, family environment factors such as dysfunctional parental rearing or disturbed family functioning are probably more specific risk factors for the onset and course of SAD-symptoms. In addition to their individual contributions, familial risk factors may also interact in terms of an accumulation of risk, as parents who pass on genes carrying psychological risks also tend to be the same parents who provide unfavourable rearing styles. Likewise, the expression of a specific genotype depends on the interplay of nature and nurture: On the one hand, the (genetic) susceptibility due to the familial aggregation of psychopathology may foster offspring's' reaction to unfavourable family environment. On the other hand, unfavourable family environment may facilitate the outcome of the (genetic) transmission of parental psychopathology.

\#\#\#Box 3 ends here\#\#\#

\section{Current limitations}

Studies may provide insight into the possible developmental pathways for SAD. Nonetheless, conclusion are hampared due to methodological shortcomings in lieu of (diagnostic) assessment and study design.

On the one hand, SAD-diagnoses are based on non-standardised assessments including dimensional and categorical approaches (e.g., questionnaires, cut-off scores), but also on structured or standardised interviews (e.g, CIDI, SCID). Findings may be affected by information processing- and mood-congruent bias.

On the other hand, the majority of studies rather reflect correlational instead of causal relationships, thus evidence for a relationship between family environment factors and offspring 
anxiety is predominantly cross-sectional. Studies were unable to clearly discern whether the parental behaviours observed are responses to children's psychopathology, or are antecedents and contributing risk factors. Therefore, whether the identified family factors actually cause childhood anxiety, still needs to be investigated. Further research that investigates mechanisms mediating the relationship between family factors and child anxiety is also called for.

Very few studies prospectively considered predictors for the natural course of the disorder, especially in young adolescent samples across the high risk period for SAD. Though it is likely that clinical characteristics of SAD, such as early age of onset, severity of symptoms, number of social fears and generalised subtype, avoidance and impairment, or comorbidities have an impact on the course of the disorder [80]; it remains basically unknown whether familial risk factors for the onset of SAD may also account for its further course. As mentioned above, the onset of SAD was predicted independently by parental psychopathology and unfavourable family environment, and also by their interaction. In contrast, the further course (e.g. persistence) of SAD was found to be rather predicted by characteristics of early SAD expressions [80] and unfavourable family environment [56]. Again, interactions suggest an accumulation of risk, namely that higher levels of parental overprotection were associated with higher persistence of offsprings' SAD when parental SAD was present. Accordingly, family environment (with parental rearing in particular) emerged as an important predictor for both the onset and course of the disorder. Findings argue for the prognostic value of early course characteristics for the future manifestation of SAD [80]. Course and outcome of SAD are however rarely characterised by simple linear relationships. Given the oscillating course of social phobia symptoms [71, 114], conclusions from the presence or absence of full diagnostic criteria are crude, neglecting the complexity and severity of the disorder, as also conditions below the diagnostic threshold lead to impairment in daily life and increase the risk for comorbid and subsequent psychopathology [31].

\section{Calling for a family-oriented approach in social anxiety disorder}

During childhood and adolescence (i.e., the core SAD-incidence period), the family system probably represents one of the major developmental contexts, in which genetic predispositions cluster and interact with environmental factors. To consider the onset and course of SAD within a more family-oriented approach may help to expand our current knowledge about SAD-risk factors, and to provide a scientific basis for prevention and intervention: Assessment of familial risk factors may 
contribute to the reliable detection of high risk populations, and to delineate differential prevention strategies incorporating these familial contributions.

Increasing progress in studying gene-environment-interactions is underway, but still scarce for phobias [36], and particularly for SAD [60]. To examine the independent and combined contributions of familial risk factors to SAD requires to longitudinally follow-up an unbiased, large representative sample across the high risk period for SAD onset and observe in its natural setting (instead of a small, cross-sectional clinically referred sample). Putative familial risk factors should be examined within one sample (instead of focusing on isolated factors), to allow for covariation among variables, but also to have sufficient sample size and statistical power to detect interaction between parental psychopathology and family environment on the risk for offspring SAD. The standardised assessment of a variety of psychopathology in offspring and their parents provides a reliable and valid basis for diagnoses. Finally, the frequent oscillations of SAD above and below the diagnostic threshold need to be considered when characterising the course of SAD.

The merits of such a family-oriented approach appear promising: The standardised assessment of offspring and parental psychopathology allows considering the associations of parental SAD and other disorders including their comorbidity with offspring SAD. Also, the specificity of the familial transmission of SAD can be explored in greater detail. Recent findings indicate at least some specificity: For example, Murray et al. [76] found that socially phobic mothers appeared more anxious, engaged less with the stranger, and were less encouraging to infant than mothers with generalised anxiety disorder or healthy controls. In addition, conditions of SAD above and below the DSM-IV diagnostic threshold can also be modelled, broadening the concept of SAD to social fears, and thereby investigating whether there is a continuum of social fears, social phobia and its subtypes, or even a graded relationship between familial risk with offspring SAD status in terms of a doseresponse-relationship [57].

\section{Summary and conclusion}

There is an antagonism between the high prevalence of SAD in the community, associated individual and societal costs, and the minority of SAD cases that receive treatment. Up to date, knowledge about reliable risk factors, their interplay and predictors for the onset and course of SAD is too limited to derive precise strategies for prevention and intervention. Given the early onset of SAD in adolescence and young adulthood, the substantial familial aggregation and the family as an important 
context for cognitive, emotional and behavioural development, parental psychopathology and unfavourable family environment appear as promising targets for research. Taking into account clinical features of SAD (i.e., different types of social fears, interaction- vs. performance-related social fears, age at first onset, anxiety-related cognitions), and other putative risk factors (i.e., somatic conditions, natal complications) may further help to illustrate the development and phenomenolgy of this earlyonset anxiety disorder. There is a lack of longitudinal studies, prospectively covering the high risk period and assessing a wider range of putative risk factors to collect detailed and methodological sound data on SAD. Though such studies are extremely time-consuming, and expensive in regard to costs and personnel required, they allow us to examine the associations and interactions of familial risk factors with the onset and course of SAD, to thereby constitute a valuable basis for targeted prevention and early intervention in adolescents and young adults at risk. 
Table 1: The familial aggregation of social anxiety disorder

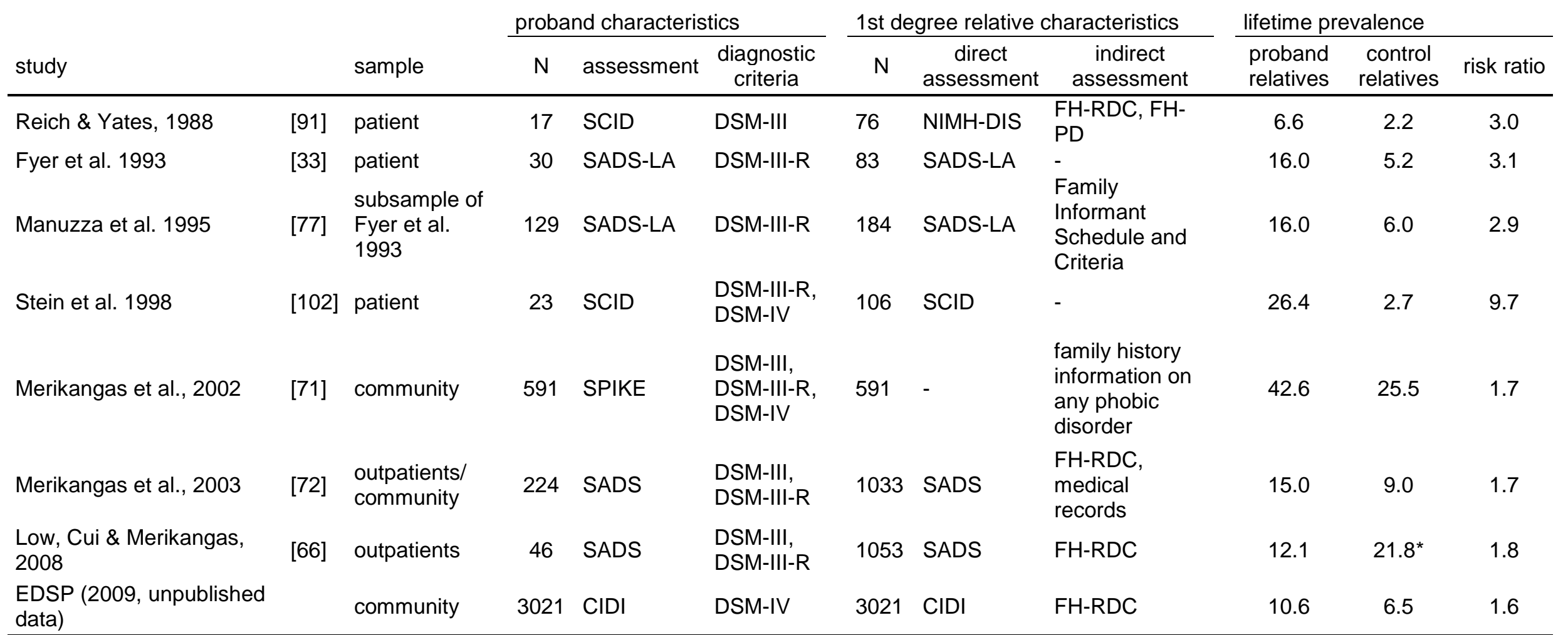

Note: *calculated from publication; when both direct and indirect information on relative's diagnostic status was available, best-estimate diagnoses were derived

Abbreviations in alphabetical order: CIDI Composite International Diagnostic Interview; DSM Diagnostic and Statistical Manual of Mental Disorders; EDSP Early Developmental Stages of Psychopathology-Study; FH-RDC Family History Research Diagnostic Criteria; FH-PD Family History for DSM-III anxiety and Personality Disorders; NIHM-DIS National Institute of Mental HealthDiagnostic Interview Schedule; SADS Schedule for Affective Disorders and Schizophrenia; SADS-LA Schedule for Affective Disorders and Schizophrenia, adopted for Lifetime Anxiety Disorders;

SCID Structured Clinical Interview for DSM-Disorders; SPIKE Structured Psychopathological Interview and Rating of the Social Consequences for Epidemiology 
Table 2: Twin and genetic studies on social fears and social anxiety disorder

\begin{tabular}{|c|c|c|c|c|c|c|c|c|c|}
\hline \multirow[b]{2}{*}{ study } & \multirow[b]{2}{*}{ traits / study outcome } & \multirow[b]{2}{*}{ population } & \multirow[b]{2}{*}{ age in years } & \multicolumn{3}{|c|}{ heritability } & \multirow[b]{2}{*}{ comment } & \multirow[b]{2}{*}{ reference } & \\
\hline & & & & total & $\begin{array}{l}\text { monozygotic } \\
\text { twins (MZ) }\end{array}$ & $\begin{array}{l}\text { dizygotic twins } \\
\text { (DZ) }\end{array}$ & & & \\
\hline $\begin{array}{l}\text { twin study } \\
\text { (Norway) }\end{array}$ & social phobia & $\begin{array}{l}81 \text { twin pairs } \\
\text { (32 MZ, } 49 \mathrm{DZ})\end{array}$ & $18-53$ & $(0.12)$ & $(0.1)$ & $(0.14)$ & $\begin{array}{l}\text { Social phobia is mainly caused by } \\
\text { environmental experiences. }\end{array}$ & Skre et al., 1993 & [97] \\
\hline MacArthur & self-reported childhood & 326 twin pairs & 7 & 0.34 social phobia & - & - & Effects of shared environment almost & Warren, Schmitz \& & \\
\hline $\begin{array}{l}\text { Longitudinal Twin } \\
\text { Study }\end{array}$ & anxiety & & & $\begin{array}{l}0.25 \text { for any anxiety } \\
\text { symptom }\end{array}$ & & & $\begin{array}{l}\text { neglegible. Higher scores on nonshared } \\
\text { environment ( } 0.64-0.70) \text { may at least in part be } \\
\text { attributable to error. }\end{array}$ & Emde, 1999 & [109] \\
\hline \multirow[t]{5}{*}{$\begin{array}{l}\text { Virginia Twin } \\
\text { Study }\end{array}$} & social phobia & $\begin{array}{l}1198 \text { male twin } \\
\text { pairs (707 MZ, } \\
491 \mathrm{DZ})\end{array}$ & $20-58$ & $\begin{array}{l}0.24 \text { social fears and } \\
\text { phobias } \\
0.20 \text { social phobia alone }\end{array}$ & - & - & $\begin{array}{l}\text { Familial aggregation was due solely to genetic } \\
\text { factors, and model fitting could not distinguish } \\
\text { between genetic and familial environmental } \\
\text { sources of twin resemblance. }\end{array}$ & Kendler et al., 2001 & [51] \\
\hline & $\begin{array}{l}\text { unreasonable fear, } \\
\text { social phobia }\end{array}$ & $\begin{array}{l}1708 \text { female } \\
\text { twin pairs }\end{array}$ & adults & $\begin{array}{l}0.51 \text { unreasonable fear } \\
\text { and social phobia } \\
0.50 \text { social phobia alone }\end{array}$ & - & - & $\begin{array}{l}\text { Familial-environmental factors appear to be of } \\
\text { little aetiological significance. }\end{array}$ & $\begin{array}{l}\text { Kendler, Karkowski \& } \\
\text { Prescott, } 1999\end{array}$ & [50] \\
\hline & social phobia & $\begin{array}{l}17 \text { mulitplex } \\
\text { families }\end{array}$ & $18-65$ & - & - & - & $\begin{array}{l}\text { No evidence for linkage between generalized } \\
\text { social phobia and } 5 \text { HTAA receptor or } 5 \text { HTT } \\
\text { transporter gene was found. }\end{array}$ & Stein et al., $1998^{*}$ & [99] \\
\hline & social phobia & $\begin{array}{l}17 \text { mulitplex } \\
\text { families }\end{array}$ & $18-65$ & - & - & - & $\begin{array}{l}\text { No evidence for the role of dopamine D2, D3 } \\
\text { and D4 receptor genes in social phobia. }\end{array}$ & Kennedy et al., $2001^{*}$ & [53] \\
\hline & social phobia & $\begin{array}{l}3086 \text { twin pairs } \\
(1210 \mathrm{MZ}, 818 \\
\text { DZ, } 1058 \mathrm{DZ} \\
\text { opposite sex) }\end{array}$ & adults & - & $\begin{array}{l}0.25 \text { males } \\
0.34 \text { females }\end{array}$ & $\begin{array}{l}0.13 \text { males } \\
0.35 \text { females } \\
0.06 \text { opposite sex }\end{array}$ & $\begin{array}{l}\text { Twin resemblance in males may be explained } \\
\text { by genetic factors, while twin resemblence in } \\
\text { females may explained by familial environment } \\
\text { factors. }\end{array}$ & Kendler et al., 2002 & [49] \\
\hline clinical twin study & $\begin{array}{l}\text { common social fears } \\
\text { (fears of eating with } \\
\text { strangers, being } \\
\text { watched writing, } \\
\text { working, trembling) }\end{array}$ & $\begin{array}{l}61 \text { twin pairs } \\
(23 \mathrm{MZ}, 38 \mathrm{DZ})\end{array}$ & $21-53$ & 0.47 & - & - & $\begin{array}{l}\text { All genetic effects are dominance effects, there } \\
\text { is no additive genetic variance. }\end{array}$ & Skre et al., 2000 & [98] \\
\hline $\begin{array}{l}\text { genome-wide } \\
\text { linkage study to } \\
\text { test for generic } \\
\text { markers }\end{array}$ & social phobia & $\begin{array}{l}163(17 \\
\text { American } \\
\text { Pedigrees })\end{array}$ & & - & - & - & $\begin{array}{l}\text { Chromosome } 16 \text { markers, recessive } \\
\text { inheritance, several markers identified; gene } \\
\text { encoding the norepinephrine transporter protein } \\
\text { maps to this region. }\end{array}$ & Gelernter et al., 2004 & [35] \\
\hline clinical study & social phobia & $\begin{array}{l}62 \text { patients and } \\
62 \text { matched } \\
\text { controls }\end{array}$ & $\begin{array}{l}\text { mean age } \\
28.8 \text { and } 29.1\end{array}$ & - & - & - & $\begin{array}{l}\text { Patients with less active } 5 \text { HTTLPR SS/SL } \\
\text { genotype scored higher on BPS than patients } \\
\text { with higher active genotype. This association } \\
\text { held after controlling for depression, but not } \\
\text { after adjusting for multiple testing. }\end{array}$ & Domschke et al., 2009 & [28] \\
\hline
\end{tabular}

Abbreviations in alphabetical order: BPS Blushing Propensity Scale; DZ dizygotic twins; MZ monozygotic twins; 5 HTTLPR SS/SL serotonin transporter (5-HTT) gene variation (5-HTTLPR) SS/S short-short / short long allele L 
Table 3: Associations between unfavourable parental rearing styles and offspring anxiety / social anxiety disorder

\begin{tabular}{|c|c|c|c|c|c|c|c|c|}
\hline \multirow{2}{*}{$\begin{array}{l}\text { parental rearing } \\
\text { assessed with }\end{array}$} & \multicolumn{2}{|c|}{ parental characteristics } & \multicolumn{3}{|c|}{ offspring characteristics } & \multirow[t]{2}{*}{ results } & \multirow[t]{2}{*}{ reference } & \\
\hline & $\mathrm{N}$ & assessment & $\mathrm{N}$ & $\begin{array}{l}\text { age in } \\
\text { years }\end{array}$ & assessment & & & \\
\hline $\begin{array}{l}\text { behavioral observation } \\
\text { during cognitive tasks }\end{array}$ & 95 mothers & ADIS-IV-P & $\begin{array}{l}43 \text { anxious } \\
\text { offspring, } 20 \\
\text { oppositional } \\
\text { deviant } \\
\text { children, } 32 \\
\text { controls }\end{array}$ & $7-15$ & $\begin{array}{l}\text { ADIS-IV-C, } \\
\text { CBCL, } \\
\text { RCMAS }\end{array}$ & $\begin{array}{l}\text { Mothers of anxious children } \\
\text { showed more involvement and } \\
\text { more negativity than mothers of } \\
\text { controls, especially when chidlren } \\
\text { were younger than } 10 \text { years of } \\
\text { age. }\end{array}$ & $\begin{array}{l}\text { Hudson \& } \\
\text { Rapee, } 2001\end{array}$ & {$[41]$} \\
\hline $\begin{array}{l}\text { behavioral observation } \\
\text { of interactions }\end{array}$ & 68 mothers & ADIS-IV & 68 & $7-15$ & K-SADS & $\begin{array}{l}\text { Mothers of anxious children were } \\
\text { less warm, irrespective of their } \\
\text { own diagnostic status. }\end{array}$ & $\begin{array}{l}\text { Moore et al., } \\
2004\end{array}$ & [74] \\
\hline $\begin{array}{l}\text { Do you feel that you } \\
\text { relate more to either } \\
\text { child a or b? Do you } \\
\text { feel you are more } \\
\text { protective of (need to } \\
\text { look after) either child } \\
\text { a or b? In comparison } \\
\text { to other parents, do } \\
\text { you feel your are more } \\
\text { protective of both of } \\
\text { the children? }\end{array}$ & $\begin{array}{l}45 \text { families } \\
\text { with two } \\
\text { children, of } \\
\text { whom one } \\
\text { had an } \\
\text { anxiety } \\
\text { disorder, } \\
\text { and } 33 \text { non- } \\
\text { referred } \\
\text { families }\end{array}$ & ADIS-IV-P & $\begin{array}{l}45 \text { anxious, } \\
33 \text { non- } \\
\text { anxious } \\
\text { children }\end{array}$ & $7-16$ & ADIS-IV-C & $\begin{array}{l}\text { Parents (especially mothers) } \\
\text { perceive themselves as more } \\
\text { protective of the anxious child } \\
\text { than of the non-anxious sibling. }\end{array}$ & $\begin{array}{l}\text { Hudson \& } \\
\text { Rapee, } 2005\end{array}$ & [43] \\
\hline PBI & - & & 224 & $7-18$ & SADS & $\begin{array}{l}\text { SADs reported lower levels of } \\
\text { maternal emotional warmth. For } \\
\text { overprotection, no differences } \\
\text { between affected and unaffected } \\
\text { individuals were found. }\end{array}$ & $\begin{array}{l}\text { Merikangas et } \\
\text { al., } 2003\end{array}$ & [72] \\
\hline EMBU-C & 190 & - & $\begin{array}{l}64 \text { offspring } \\
\text { with SAD, } \\
126 \text { controls }\end{array}$ & $8-18$ & SAS & $\begin{array}{l}\text { Offspring with SAD reported lower } \\
\text { family sociability and emotional } \\
\text { warmth, more parental rejection; } \\
\text { parents of SAD-offspring reported } \\
\text { higher dependence upon the } \\
\text { opinion of others, no differences } \\
\text { found for overprotection or } \\
\text { parental encouragement. }\end{array}$ & $\begin{array}{l}\text { Bögels et al., } \\
2001\end{array}$ & {$[15]$} \\
\hline
\end{tabular}


Table 3: Associations between unfavourable parental rearing styles and offspring anxiety / social anxiety disorder (continued)

\begin{tabular}{|c|c|c|c|c|c|c|c|c|}
\hline $\begin{array}{l}\text { behavioral observation } \\
\text { of family decision } \\
\text { making task, CRBI }\end{array}$ & $\begin{array}{l}17 \text { mothers, } \\
17 \text { fathers }\end{array}$ & - & $\begin{array}{l}17 \text { anxiety- } \\
\text { disordered } \\
\text { offspring }\end{array}$ & $9-12$ & $\begin{array}{l}\text { ADIS-P if } \\
\text { age }<12 \\
\text { ADIS-C if } \\
\text { age }>=12 \\
\text { years }\end{array}$ & $\begin{array}{l}\text { Anxiety-disordered children rated } \\
\text { their mothers (but not their } \\
\text { fathers) as more restrictive, less } \\
\text { accepting. }\end{array}$ & $\begin{array}{l}\text { Siqueland et } \\
\text { al., } 1996\end{array}$ & [96] \\
\hline FEQ & - & - & 3649 & $9-17$ & $\begin{array}{l}\text { SASC-R / } \\
\text { SAS-A }\end{array}$ & $\begin{array}{l}\text { SADs perceived greater parental } \\
\text { shame overconcern, restriction of } \\
\text { family sociability. }\end{array}$ & $\begin{array}{l}\text { Johnson et al., } \\
2005\end{array}$ & [45] \\
\hline FEQ & 404 parents & - & 2708 & $12-18$ & $\begin{array}{l}\text { RCMAS, } \\
\text { SAS-A, } \\
\text { CDI }\end{array}$ & $\begin{array}{l}\text { SADs rated their parents as more } \\
\text { socially isolating, more concerned } \\
\text { about others opinions, more } \\
\text { ashamed of their shyess and poor } \\
\text { performance, less socially active. }\end{array}$ & $\begin{array}{l}\text { Caster, } \\
\text { Inderbitzen \& } \\
\text { Hope, } 1999\end{array}$ & [18] \\
\hline FEE & - & - & 1395 & $14-17$ & CIDI & $\begin{array}{l}\text { SADs reported more parental } \\
\text { overprotection, rejection, and } \\
\text { lower levels of emotional warmth. }\end{array}$ & $\begin{array}{l}\text { Lieb et al., } \\
2000\end{array}$ & [64] \\
\hline CRBI & $\begin{array}{l}816 \text { mothers } \\
\text { with } \\
\text { depressive } \\
\text { symptoms }\end{array}$ & $\begin{array}{l}\text { SCID, K- } \\
\text { SADS-E }\end{array}$ & 816 & $\begin{array}{l}\text { mean } \\
15.0\end{array}$ & K-SADS-E & $\begin{array}{l}\text { Maternal control predicted } \\
\text { offspring anxiety. }\end{array}$ & $\begin{array}{l}\text { McClure et al., } \\
2001\end{array}$ & [69] \\
\hline EMBU & - & - & $\begin{array}{l}16 \text { SAD, } 43 \\
\text { with } \\
\text { agoraphobia } \\
100 \text { controls }\end{array}$ & $18+$ & & $\begin{array}{l}\text { SADs rated their parents as more } \\
\text { rejective, overprotective, and less } \\
\text { emotionally warm than children } \\
\text { with agoraphobia and healthy } \\
\text { controls. }\end{array}$ & $\begin{array}{l}\text { Arrindel et al., } \\
1989\end{array}$ & {$[6]$} \\
\hline PBI & - & - & 8232 & $18+$ & CIDI & $\begin{array}{l}\text { Lack of maternal and paternal } \\
\text { care, maternal overprotection, but } \\
\text { not maternal or paternal } \\
\text { authoritianism were associated } \\
\text { with SAD. }\end{array}$ & $\begin{array}{l}\text { Heider et al., } \\
2008\end{array}$ & [37] \\
\hline \multicolumn{9}{|c|}{$\begin{array}{l}\text { Abbreviations in alphabetical order: ADIS-IV-P/C Anxiety Disorders Interview Schedule for Children, Parents Version; CBCL Child Behavior Checklist; CIDI } \\
\text { Composite International Diagnostic Interview; CRPBI Childs Report of Parental Behavior Inventory; CRPR Childs Report of Parental Behavior Inventory; } \\
\text { EMBU-C Egna Minnen Betraffande Uppfostran (e.g. Questionnaire of Recalled Parental Rearing Practices); FEE Fragebogen zum Erinnerten Elterlichen } \\
\text { Erziehungsverhalten (Questionnaire of Recalled Parental Rearing Behavior); FEQ Family Expressiveness Questionnaire; K-SADS Kiddie-Schedule for } \\
\text { Affective Disorders and Schizophrenia for School-Age Children; PBI Parental Bonding Instrument; PSP Preschool Socioaffective Profile; RCMAS Revised } \\
\text { Children's Manifest Anxiety Scale; SAD Social Anxiety Disorder; SAS, SAS-A Social Anxiety Scale (for Adolescents); SASC-R Social Anxiety Scale for } \\
\text { Children-Revised; SCID Structured Clinical Interview for DSM-Disorders; SIAS Social Interaction Anxiety Scale; SPAI-C Social Phobia and Anxiety Inventor }\end{array}$} \\
\hline
\end{tabular}




\section{References}

1. Alfano CA, Beidel DC, Turner SM (2006) Cognitive correlates of social phobia among children and adolescents. J Abnorm Child Psychol 34:189-201

2. Alonso J, Angermeyer MC, Bernert S, Bruffaerts R, Brugha TS, Bryson H, et al (2004) Disability and quality of life impact of mental disorders in Europe: Results from the European Study of the Epidemiology of Mental Disorders (ESEMeD) project. Acta Psychiatr Scand 109:38-46

3. American Psychiatric Association (1987) DSM-III-R. Diagnostic and Statistical Manual of Mental Disorders. Washington, DC: Author. Author, Washington, DC

4. American Psychiatric Association (1994) DSM-IV. Diagnostic and Statistical Manual of Mental Disorders. Author, Washington, DC

5. American Psychiatric Association (2000) DSM-IV-TR. Diagnostic and Statistical Manual of Mental Disorders. Text revision. Author, Washingston, DC

6. Arrindell WA, Kwee MG, Methorst GJ, Van der Ende J, et al (1989) Perceived parental rearing styles of agoraphobic and socially phobic in-patients. Br J Psychiatry 155:526-535

7. Ballash NG, Pemble MK, Usui WM, Buckley AF, Woodruff-Borden J (2006) Family functioning, perceived control, and anxiety: A mediational model. J Anxiety Disord 20:486

8. Barrett PM, Rapee RM, Dadds MR, Ryan ND (1996) Family enhancement of cognitive style in anxious and aggressive children. J Abnorm Child Psychol 24:187-203

9. Becker ES, Türke V, Neumer S, Soeder U, Krause P, Margraf J (2000) Incidence and prevalence rates of mental disorders in a community sample of young women: Results of the "Dresden Study". In: Manz R, Kirch W (eds) Public Health Research and Practice: Report of the Public Health Reserach Association Saxony. S. Roederer, Regensburg, p 259-291

10. Beesdo K, Bittner A, Pine DS, Stein MB, Höfler M, Lieb R, Wittchen H-U (2007) Incidence of social anxiety disorder and the consistent risk for secondary depression in the first three decades of life. Arch Gen Psychiatry 64:903-912

11. Biederman J, Rosenbaum JF, Hirshfeld DR, Faraone SV, Bolduc EA, Gersten M, et al (1990) Psychiatric correlates of behavioral inhibition in young children of parents with and without psychiatric disorders. Arch Gen Psychiatry 47:21-26

12. Bienvenu OJ, Hettema JM, Neale MC, Prescott CA, Kendler KS (2007) Low extraversion and high neuroticism as indices of genetic and environmental risk for social phobia, agoraphobia, and animal phobia. Am J Psychiatry 164:1714-1721

13. Boer F, Lindhout I, Silverman WK, Treffers PDA (2001) Family and genetic influences: Is anxiety 'all in the family'? In: Anxiety disorders in children and adolescents: Research, assessment and intervention. Cambridge University Press, New York, NY US, p 235-254

14. Bögels SM, van Dongen L, Muris PU (2003) Family influences on dysfunctional thinking in anxious children. Infant Child Dev 12:243-252.

15. Bögels SM, van Oosten A, Muris P, Smulders D (2001) Familial correlates of social anxiety in children and adolescents. Behav Res Ther 39:273-287

16. Bruce SE, Yonkers KA, Otto MW, Eisen JL, Weisberg RB, Pagano ME, et al (2005) Influence of psychiatric comorbidity on recovery and recurrence in generalized anxiety disorder, social phobia, and panic disorder: A 12-year prospective study. Am J Psychiatry 162:1179-1187

17. Bruch MA (1989) Familial and developmental antecendents of social phobia: Issues and findings. Clin Psychol Rev 9:37-47

18. Caster JB, Inderbitzen HM, Hope DA (1999) Relationship between youth and parent perceptions of family environment and social anxiety. J Anxiety Disord 13:237-251

19. Chavira D, Stein MB, Malcarne VJ (2002) Scrutinizing the relationship between shyness and social phobia. J Anxiety Disord 16:585-598

20. Cheek JM, Krasnoperova EN (1999) Varieties of shyness in adolesence and adulthood. In: Schmidt LA, Schulkin J (eds) Extreme fear, shyness, and social phobia: Origins, biological mechanisms and clinical outcomes. Oxford University Press, New York, p 224-250

21. Christensen PN, Stein MB, Means-Christensen A (2003) Social anxiety and interpersonal perception: a social relations model analysis. Behav Res Ther 41:1355-1371

22. Cobham VE, Dadds MR, Spence SH (1999) Anxious children and their parents: What they do expect? J Clin Child Psychol 28:220-231

23. Davidson JR, Hughes DL, George LK, Blazer DG (1993) The epidemiology of social phobia: Findings from the Duke Epidemiological Catchment Area Study. Psychol Med 23:709-718 
24. de Graaf R, Bijl RV, Ravelli A, Smit F, Vollebergh WAM (2002a) Predictors of first incidence of DSM III R psychiatric disorders in the general population: findings from the Netherlands Mental Health Survey and Incidence Study. Acta Psychiatr Scand 106:303-313

25. de Rosnay M, Cooper PJ, Tsigaras N, Murray L (2006) Transmission of social anxiety from mother to infant: An experimental study using a social referencing paradigm Behav Res Ther 44:1165-1175

26. DiLalla LF, Kagan J, Reznick JS (1994) Genetic etiology of behavioral inhibition among 2year-old children. Infant Behav Dev 17:405-412

27. Distel MA, Vink JM, Willemsen G, Middeldorp CM, Merckelbach HLGJ, Boomsma DI (2008) Heritability of self-reported phobic fear. Behav Genet 38:24-33

28. Domschke K, Stevens S, Beck B, Baffa A, Hohoff C, Deckert J, Gerlach AL (2009) Blushing propensity in social anxiety disorder: influence of serotonin transporter gene variation. J Neur Trans 116:663-666

29. Elizabeth J, King N, Ollendick TH, Gullone E, Tonge B, Watson S, et al (2006) Social anxiety disorder in children and youth: A research update on aetiological factors. Couns Psychol $Q$ 19:151-163

30. Essau CA, Conradt J, Petermann F (2002) Course and outcome of anxiety disorders in adolescents. J Anxiety Disord 16:67-81

31. Fehm L, Beesdo K, Jacobi F, Fiedler A (2008) Social phobia above and below the diagnostic threshold: Prevalence, comorbidity and impairment in the general population. Soc Psychiatry Psychiatr Epidemiol 43:257-265

32. Fehm L, Pelissolo A, Furmark T, Wittchen H-U (2005) Size and burden of social phobia in Europe. Eur Neuropsychopharmacology 15:453-462

33. Fyer AJ, Mannuzza S, Chapman TF, Liebowitz MR, Klein DF (1993) A direct interview family study of social phobia. Arch Gen Psychiatry 50:286-293

34. Fyer AJ, Mannuzza S, Chapman TF, Martin LY, Klein DF (1995) Specificity in familial aggregation of phobic disorders. Arch Gen Psychiatry 52:564-573

35. Gelernter J, Page GP, Stein MB, Woods SW (2004) Genome-wide linkage scan for loci predisposing to social phobia: Evidence for a chromosome 16 risk locus. Am J Psychiatry 161:59-66

36. Gregory AM, Lau JF, Eley TC (2008) Finding gene-environment interactions for phobias. Eur Arch Psychiatry Clin Neurosci 258:76-81

37. Heider D, Matschinger H, Bernert S, Alonso J, Brugha TS, Bruffaerts R, et al (2008) Adverse parenting as a risk factor in the occurence of anxiety disorders. Soc Psychiatry Psychiatr Epidemiol 43:266-272

38. Heimberg RG, Holt CS, Schneier FR, Spitzer RL, Liebowitz MR (1993) The issue of subtypes in the diagnosis of social phobia. J Anxiety Disord 7:249-269

39. Heiser NA, Turner SM, Beidel DC, Roberson-Nay R (2009) Differentiating social phobia from shyness. J Anxiety Disord 23: 469-476

40. Hettema JM, Prescott CA, Myers JM, Neale MC, Kendler KS (2005) The structure of genetic and environmental risk factors for anxiety disorders in men and women. Arch Gen Psychiatry 62:182-189

41. Hirshfeld DR, Rosenbaum JF, Biederman J, Bolduc EA, Faraone SV, Snidman N, et al (1992) Stable behavioral inhibition and its association with anxiety disorder. J Am Acad Child Adolesc Psychiatry 31:103-111

42. Hudson JL, Rapee RM (2001) Parent-child interactions and anxiety disorders: an observational study. Behav Res Ther 39:1411-1427

43. Hudson JL, Rapee RM (2005) Parental perceptions of overprotection: Specific to anxious children or shared between siblings? Behaviour Change 22:185-194

44. Issakidis C, Andrews G (2002) Service utilisation for anxiety in an Australian community sample. Soc Psychiatry Psychiatr Epidemiol 37:153-163

45. Johnson HS, Inderbitzen-Nolan HM, Schapman AM (2005) A comparison between socially anxious and depressive symptomatology in youth: a focus on perceived family environment. $J$ Anxiety Disord 19:423-442

46. Kagan J (1989) Temperamental contributions to social behavior. American Psychologist 44:668-674

47. Katzelnick DJ, Kobak KA, DeLeire T, Henk HJ, Greist JH, Davidson JRT, Schneier FR, Stein MB, Helstad CP (2001) Impact of generalized social anxiety disorder in managed care. Am J Psychiatry 158:1999-2007

48. Keller MB (2006) Social anxiety disorder clinical course and outcome: Review of Harvard/Brown Anxiety Research Project (HARP) findings. J Clin Psychiatry 67:14-19 
49. Kendler KS, Jacobson KC, Myers J, Prescott CA (2002) Sex differences in genetic and environmental risk factors for irrational fears and phobias. Psycho Med 32:209-217

50. Kendler KS, Karkowski LM, Prescott CA (1999) Fears and phobias: Reliability and heritability. PsycholMed 29:539-553

51. Kendler KS, Myers J, Prescott CA, Neale MC (2001) The genetic epidemiology of irrational fears and phobias in men. Arch Gen Psychiatry 58:257-265

52. Kendler KS, Neale MC, Kessler RC, Heath AC, Eaves LJ (1992) The genetic epidemiology of phobias in women: The interrelationship of agoraphobia, social phobia, situational phobia, and simple phobia. Arch Gen Psychiatry 49:273-281

53. Kennedy JL, Neves-Pereira M, King N, Lizak MV, Basile VS, Chartier MJ, et al (2001) Dopamine system genes not linked to social phobia. Psychiatr Genetics 11:213-217

54. Kessler RC, McGonagle KA, Zhao S, Nelson CB, Hughes M, Eshleman S, et al (1994) Lifetime and 12-month prevalence of DSM-III-R psychiatric disorders in the United States: Results from the National Comorbidity Study. Arch Gen Psychiatry 51:8-19

55. Kim-Cohen J, Caspi A, Moffitt TE, Harrington HL, Milne BJ, Poulton R (2003) Prior juvenile diagnosis in adults with mental disorders: developmental follow-back of a prospectivelongitudinal cohort. Arch Gen Psychiatry 60:709-717

56. Knappe S, Beesdo K, Fehm L, Höfler M, Lieb R, Wittchen H-U (2009) Do parental psychopathology and unfavorable family environment predict the persistence of social phobia? J Anxiety Disord 23:986-994

57. Knappe S, Beesdo K, Fehm L, Lieb R, Wittchen H-U (2009) Associations of familial risk factors with social fears and social phobia: Evidence for the continuum hypothesis in social anxiety disorder? J Neur Trans 116:639-648

58. Knappe S, Lieb R, Beesdo K, Fehm L, Low NCP, Gloster AT, et al (2009) The role of parental psychopathology and family eEnvironment for social phobia in the first three decades of life. Depress Anxiety 26:363-370

59. Last CG, Perrin S, Hersen M, Kazdin AE (1996) A prospective study of childhood anxiety disorders. J Am Acad Child Adolesc Psychiatry 35:1502-1510

60. Lau JF, Gregory AM, Goldwin MA, Pine DS, Eley TC (2007) Assessing gene-environment interactions on anxiety symptom subtypes across childhood and adolescence. Dev Psychopathol 19:1129-1146

61. Leon AC, Portera L, Weisman MM (1995) The social costs of anxiety disorders. Br J Psychiatry 166:19-22

62. Lépine J-P (2002) The epidemiology of anxiety disorders: Prevalence and societal costs. J Clin Psychiatry 63:4-8

63. Lester KJ, Field AP, Oliver S, Cartwright-Hatton S (2009) Do anxious parents interpretive biases towards threat extend into their child's environment? Behav Res Ther 47:170-174

64. Lieb R, Wittchen H-U, Höfler M, Fuetsch M, Stein MB, Merikangas KR (2000) Parental psychopathology, parenting styles and the risk of social phobia in offspring: a prospectivelongitudinal community study. Arch Gen Psychiatry 57:859-866

65. Lochner C, Hemmings S, Seedat S, Kinnear C, Schoeman R, Annerbrink K, et al (2007) Genetics and personality traits in patients with social anxiety disorder: A case-control study in South Africa. Eur Neuropsychopharmacol 17:321-327

66. Low NCP, Cui L, Merikangas KR (2008) Community versus clinic sampling: effect on the familial aggregation of anxiety disorders. Biol Psychiatry 63:884-890

67. Manassis K, Bradley SJ (1994) The development of childhood anxiety disorders: toward an integrated model. J Appl Dev Psychol 15:345-366

68. Mannuzza S, Schneier FR, Chapman TF, Liebowitz MR, Klein DF, Fyer AJ (1995) Generalized social phobia: Reliability and validity. Arch Gen Psychiatry 52:230-237

69. McClure EB, Brennan PA, Hammen C, Le Brocque RM (2001) Parental anxiety disorders, child anxiety disorders, and the perceived parent-child relationship in an Australian high Risk Sample. J Abnorm Child Psychol 29:1-10

70. McLeod BD, Wood JJ, Weisz JR (2007) Examining the association between parenting and childhood anxiety: A meta-analysis. Clin Psychol Rev 27:155-172

71. Merikangas KR, Avenevoli S, Acharyya S, Zhang H, Angst J (2002) The spectrum of social phobia in the Zurich Cohort Study of Young Adults. Biol Psychiatry 51:81-91

72. Merikangas KR, Lieb R, Wittchen H-U, Aveneoli S (2003) Family and high-risk studies of social anxiety disorder. Acta Psychiatr Scand 108:28-37

73. Middeldorp CM, Birley AJ, Cath DC, Gillespie NA, Willemsen G, Statham DJ, et al (2005) Familial clustering of major depression and anxiety disorders in Australian and Dutch twins and siblings. Twin Res Human Genet 8:609-615 
74. Moore PS, Whaley SE, Sigman M (2004) Interactions between mothers and children: impacts of maternal and child anxiety. J Abnorm Psychol 113:471-476

75. Muris $\mathrm{P}$, Steerneman $\mathrm{P}$, Merckelbach H, Meesters $\mathrm{C}$ (1996) The role of parental fearfulness and modeling in children. Behav Res Ther 34:265-268

76. Murray L, Cooper P, Creswell C, Schofield E, Sack C (2007) The effects of maternal social phobia on mother-infant interactions and infant social responsiveness. J Child Psychol Psychiatry 48:45-52

77. Murray L, de Rosnay M, Pearson J, Bergeron C, Schofield E, Royal-Lawson M, et al (2008) Intergenerational transmission of social anxiety: The role of social referencing processes in infancy. Child Devt 79:1049-1064

78. Nelson EC, Grant JD, Bucholz KK, Glowinsi A, Madden PAF, Reich W, et al (2000) Social phobia in a population-based female adolescent twin sample: co-morbidity and associated suicide-related symptoms. Psychol Med 30:797-804

79. Neufeld KJ, Swartz KL, Bienvenu OJ, Eaton WW, Cai G (1999) Incidence of DIS/DSM-IV social phobia in adults. Acta Psychiatr Scand 100:186-192

80. Noyes R, Holt CS, Woodman CL (2005) Natural course of anxiety disorders. In: Mavissakalian MR, Prien RF (eds) Long-term treatment of anxiety disorders. American Psychiatric Press, Inc., p 1-48

81. Olfson M, Guardino M, Struening E, Schneider FR, Hellman F, Klein DF (2000) Barriers to the treatment of social anxiety. Am J Psychiatry 157:521-527

82. Ollendick TH, Hirshfeld-Becker DR (2002) The developmental psychopathology of social anxiety disorder. Biol Psychiatry 21:44-58

83. Ollendick TH, Vasey MW, King NJ, Vasey MW, Dadds MR (2001) Operant conditioning influences in childhood anxiety. In: The developmental psychopathology of anxiety. Oxford University Press, New York, NY, US, p 231-252

84. Ormel J, Petukhova M, Chatterji S, Aguilar-Gaxiola S, Alonso J, Angermeyer MC, et al (2008) Disability and treatment of specific mental and physical disorders across the world. $\mathrm{Br} \mathrm{J}$ Psychiatry 192:368-375

85. Patel A, Knapp M, Henderson J, Baldwin D (2002) The economic consequences of social phobia. J Affective Disord 68:221-233

86. Peleg-Popko O, Dar R (2001) Marital quality, family patterns, and children's fears and social anxiety. Contemporary Family Therapy 23:465-487

87. Pine DS, Cohen P, Gurley D, Brook J, Ma Y (1998) The risk for early-adulthood anxiety and depressive disorders in adolescents with anxiety and depressive disorders. Arch Gen Psychiatry 55:56-64

88. Prior M, Smart D, Sanson A, Oberklaid F (2000) Does shy-inhibited temperament in childhood lead to anxiety problems in adolescence? J Am Acad Child Adolesc Psychiatry 39:461-468

89. Rapee RM, Spence SH (2004) The etiology of social phobia: empirical evidence and an initial model. Clin Psychol Rev 24:737-767

90. Reich J, Goldenberg I, Goisman R, Vasile R, Goisman R, Keller M (1994) A prospective, follow-along study of the course of social phobia: II. Testing for basic predictors of course. J Nerv Ment Dis 182:297-301

91. Reich JH, Yates W (1988) Family history of psychiatric disorders in social phobia. Compr Psychiatry 29:72-75

92. Robinson JL, Kagan J, Reznick JS, Corley R (1992) The heritability of inhibited and uninhibited behavior: A twin study. Dev Psychol 28:1030-1037

93. Rosenbaum ED, Biederman J, Hirshfeld DR, Bolduc EA, Faraone SV, Kagan J, Snidman N, Reznick JS (1991) Further evidence of an association between behavioral inhibition and anxiety disorders: results from a family study of children from a non-clinical sample. J Psychiatr Res 25:49-65

94. Rubin KH, Nelson LJ, Hastings P, Asendorpf J (1999) The transaction between parents' perceptions of their children's shyness and their parenting styles. Intl J Behav Dev 23:937-957

95. Runge J, Beesdo K, Lieb R, Wittchen H-U (2008) Wie häufig nehmen Jugendliche und junge Erwachsene mit Angststörungen eine psychotherapeutische Behandlung in Anspruch?[How frequent is psychotherapy utilisation by adolescents and young adults with anxiety disorders]. Verhaltenstherapie 18:26-34

96. Siqueland L, Kendall PC, Steinberg L (1996) Anxiety in children: perceived family environments and observed family interaction. J Clin Child Psychol 25:225-237

97. Skre I, Onstad S, Torgersen S, Lygren S (1993) A twin study of DSM-III-R anxiety disorders. Acta Psychiatr Scand 88:85-92

98. Skre I, Onstad S, Torgersen S, Lygren S, Kringlen E (2000) The heritability of common phobic fear: A twin study of a clinical sample. J Anxiety Disord 14:549-562 
99. Stein MB, Chartier MJ, Kozak MV, King N, Kennedy JL (1998) Genetic linkage to the serotonin transporter protein and $5 \mathrm{HT}$-sub(2A ) receptor genes excluded in generalized social phobia. Psychiatr Res 81:283-291

100. Stein MB, Chartier MJ, Lizak MV, Jang KL (2001) Familial aggregation of anxiety-related quantitative traits in generalized social phobia. Am J Medic Genet (Neuropsychiatric Genetics) 105:79-83

101. Stein MB, Chavira DA (1998) Subtypes of social phobia and comorbidity with depression and other anxiety disorders J Affective Disord 50:11-16

102. Stein MB, Torgrud LJ, Walker JR, Chartier MJ, Hazen AL, Kozak MV, et al (1998) A directinterview family study of generalized social phobia. Am J Psychiatry 155:90-97

103. Stevenson-Hinde J, Shouldice A (1990) Fear and attachment in 2,5 year olds. Br J Dev Psychol 8:319-333

104. Suveg C, Zeman J, Flannery-Schroeder E, Cassano M (2005) Emotion socialization in families of children with an anxiety disorder. J Abnorm Child Psychol 33:145

105. Tamplin A, Goodyer IM (2001) Family functioning in adolescents at high and low risk for major depressive disorder. Eur Child Adolesc Psychiatry 10:170-179

106. Tillfors M, Furmark T, Ekselius L, Fredrikson M (2004) Social phobia and avoidant personality disorder: one spectrum disorder. Nord J Psychiatry 58:147-152

107. Turner SM, Beidel DC, Roberson-Nay R, Tervo K (2003) Parenting behaviors in parents with anxiety disorders. Behav Res Ther 41:541-554

108. Van Ameringen M, Mancini C, Oakman JM (1998) The relationship of behavioral inhibition and shyness to anxiety disorder. J Nerv Ment Dis 186:425-431

109. Warren SL, Schmitz S, Emde RN (1999) Behavioral genetic analyses of self-reported anxiety at 7 years of age. J Am Acad Child Adolesc Psychiatry 38:1403-1408

110. Weissman MM, Bland RC, Canino GJ, Greenwald S, Lee CK, Newman SC, et al (1996) The cross-national epidemiology of social phobia: a preliminary report. Int Clin Psychopharmacol 11:9-14

111. Whaley SE, Pinto A, Sigman M (1999) Characterizing interactions between anxious mothers and their children. J Consult Clin Psychol 67:826-836

112. Wilson JK, Rapee RM (2005) Interpretative biases in social phobia: content specificity and the effects of depression. Cogn Ther Res 29:315-331

113. Wittchen H-U, Fehm L (2001) Epidemiology, patterns of comorbidity and associated disabilities of social phobia. Psychiatr Clin North Am 24:617-641

114. Wittchen H-U, Lieb R, Pfister H, Schuster $P(2000)$ The waxing and waning of mental disorders: Evaluating the stability of syndromes of mental disorders in the population. Compr Psychiatry 41:122-132

115. Wittchen HU, Stein MB, Kessler RC (1999) Social fears and social phobia in a community sample of adolescents and young adults: prevalence, risk factors, and comorbidity. Psychol Med 29:309-323

116. Wood JJ, McLeod BD, Sigman M, Hwang W-C, Chu BC (2003) Parenting and childhood anxiety: theory, empirical findings, and future directions. J Child Psychol Psychiatry 44:134151

117. Woodward LJ, Fergusson DM (2001) Life course outcomes of young people with anxiety disorders in adolescence. J Am Acad Child Adolesc Psychiatry 40:1086-1093

118. Yonkers KA, Dyck IR, Keller MB (2001) An eight year longitudinal comparison of clinical course and characteristics of social phobia among men and women. Psychiatr Serv 52:637643 